\title{
Cell-specific and roasting-dependent regulation of the Keap1/Nrf2 pathway by coffee extracts
}

\author{
ALEXANDROS PRIFTIS $^{1}$, ANTONIA-EUGENIA ANGELI-TERZIDOU ${ }^{1}$, ARISTIDIS S. VESKOUKIS ${ }^{1}$, \\ DEMETRIOS A. SPANDIDOS ${ }^{2}$ and DIMITRIOS KOURETAS ${ }^{1}$ \\ ${ }^{1}$ Department of Biochemistry and Biotechnology, University of Thessaly, 41500 Larissa; ${ }^{2}$ Laboratory of \\ Clinical Virology, University of Crete, Medical School, 71409 Heraklion, Crete, Greece
}

Received March 19, 2018; Accepted April 24, 2018

DOI: $10.3892 / \mathrm{mmr} .2018 .8924$

\begin{abstract}
Coffee is a popular beverage that contains various bioactive compounds. However, its molecular mechanism of action is not fully elucidated. In this context, two previously characterized coffee extracts, a lightly roasted and the corresponding green one, were investigated for their effect on nuclear factor erythroid 2-related factor 2 (Nrf2) target gene expression in myoblasts and endothelial cells using quantitative PCR. The tested concentrations were non-cytotoxic and led to improved redox cell status, as was evident by increased reduced glutathione (GSH) levels. In both cell lines, the roasted extract upregulated gene expression more readily than its green counterpart leading to increased NAD $(\mathrm{P}) \mathrm{H}$ quinone dehydrogenase 1 and $\gamma$-glutamyl cysteine ligase catalytic subunit, among others. The green extract had a mixed effect on the endothelial cells, while, as regards the myoblasts it caused the downregulation of some Nrf-target genes. Therefore, a potential dose- and roasting-dependent mechanism is proposed in the current study, accounting for coffee's antioxidant activity.
\end{abstract}

\section{Introduction}

Reactive oxygen species (ROS) are produced normally by metabolism, inflammation, phagocytosis and other physiological biological processes. ROS can be harmful when in excess; however, some levels are required to maintain cellular homeostasis through redox cell signalling (1). When the intracellular concentration of free radicals is excessive, they

Correspondence to: Professor Dimitrios Kouretas, Department of Biochemistry and Biotechnology, University of Thessaly, Viopolis, 41500 Larissa, Greece

Email: dkouret@uth.gr

Abbreviations: ROS, reactive oxygen species; GSH, reduced form of glutathione; TPC, total polyphenolic content; Nrf2, nuclear factor erythroid 2-related factor 2

Key words: coffee, roasting, polyphenols, nuclear factor erythroid 2-related factor 2, glutathione interact with and cause oxidative damage to proteins, lipids and DNA (2). Oxidative stress has been associated with a variety of pathological conditions, including cancer, diabetes, obesity and neurodegenerative diseases $(3,4)$. In addition, it occurs frequently in muscle tissue and especially during intense exercise $(5,6)$. Furthermore, oxidative stress-induced damage of the vascular endothelium is one of the most important factors regulating aetiology of cardiovascular diseases $(7,8)$. Indeed, oxidative stress in endothelial cells induces acute and chronic phases of leukocyte adhesion to the endothelium (9). The interaction between ROS and nitric oxide sets off a vicious cycle, which results in inflammation (7). Furthermore, ROS, such as $\mathrm{H}_{2} \mathrm{O}_{2}$, can be diffused throughout endothelial cells and react with cysteine groups of proteins modifying their function (10). Thus, in an oxidative stress context, endothelial cells may lose integrity, progress to senescence and detach into the circulation (11).

Every organism that dwells in the presence of oxygen, contains a variety of endogenous antioxidant mechanisms including both enzymes and non-enzymatic metabolites (12). The most significant intracellular antioxidant compound is reduced glutathione (GSH), a tripeptide consisting of glutamic acid, glycine and cysteine, with the latter containing a sulphydryl group responsible for its antioxidant properties (13). Apart from the endogenous mechanisms, diet is a frequent supplier of antioxidant compounds, including polyphenols present in plants (14). Polyphenolic compounds are products of plant secondary metabolism playing an important role in cellular functions. When plant foods are consumed, the absorbed polyphenols may elicit a variety of important bioactivities having beneficial effects on human health $(15,16)$. Polyphenolic compounds can also be found in coffee, one of the most popular beverage throughout the world due to its pleasant taste and aroma as well as its stimulating effect (17). Coffee annual production exceeds $8 \mathrm{Mt}$ and the average daily consumption is approximately 2.3 billion cups (18). Traditionally, the beneficial effects of coffee consumption on human health have been mainly attributed to caffeine, which is its most widely investigated ingredient. Nevertheless, there also other components, such as chlorogenic acids (CGA) that contribute to its valuable antioxidant properties (19). Several studies investigated the quantity, and have reported the potent antioxidant and disease-related beneficial properties of CGAs (20-22). 
However, despite the fact that coffee beans undergo roasting before their consumption, there is not much evidence on the effects of roasting on coffee composition, nor the differences between green and roasted coffee beans regarding their antioxidant activity (23-25). Indeed, it is known that the roasting procedure, which differs between coffee varieties, greatly affects CGAs leading to their breakdown and the formation of products, which may alter the antioxidant capacity of coffee beans $(23,26,27)$. Therefore, the aim of the present study was to examine the effects of a green and a roasted $C$. arabica extract on nuclear factor erythroid 2-related factor 2 (Nrf2)-target gene expression in two cell lines.

\section{Materials and methods}

Coffee beans and roasting conditions. Both the green and roasted coffee bean varieties were provided from our collaborators (Coffee Island SA, Athens, Greece). The roasted beans were roasted for $4 \mathrm{~min}$ at $215^{\circ} \mathrm{C}$ (corresponding to a light roast).

Preparation of the extracts from coffee beans. For both the green and roasted beans a $10 \% \mathrm{w} / \mathrm{v}$ extract in $\mathrm{H}_{2} \mathrm{O}$ was prepared. The beans were grounded using mortar and pestle, then a brief sonication treatment was applied for $20 \mathrm{~min}$ (70\% amplitude, $0.7 \mathrm{sec}$ cycle) and finally they were stirred for $20 \mathrm{~min}$ in moderate heat $\left(35^{\circ} \mathrm{C}\right)$. After centrifugation $\left(7,000 \mathrm{x} \mathrm{g}, 10 \mathrm{~min}, 10^{\circ} \mathrm{C}\right)$, each extract was stored in aliquots and kept at $-80^{\circ} \mathrm{C}$ for further analysis.

Cell culture conditions. The endothelial EA.hy926 cells were donated by Professor Koukoulis (University of Thessaly, Larissa, Greece), while the $\mathrm{C} 2 \mathrm{C} 12$ muscle cells were donated by Professor Koutsilieris (National and Kapodistrian University of Athens, Athens, Greece). The cells were cultured in normal Dulbecco's modified Eagle's medium (DMEM) containing $10 \%(\mathrm{v} / \mathrm{v})$ fetal bovine serum (FBS), $2 \mathrm{mM}$ L-glutamine, $100 \mathrm{U} / \mathrm{ml}$ of penicillin and $100 \mathrm{U} / \mathrm{ml}$ of streptomycin (all purchased from Gibco, Paisley, UK) in plastic disposable tissue culture flasks at $37^{\circ} \mathrm{C}$ in $5 \%$ carbon dioxide.

Treatment of the cells with the coffee extracts. Cells were seeded in culture flasks and incubated for $24 \mathrm{~h}$. The medium was then removed and replaced with serum-free medium containing the coffee extracts at non-cytotoxic concentrations. The cells were treated with the extracts (or just with serum-free medium for the control flasks) for $24 \mathrm{~h}$ and were then trypsinised, collected and centrifuged twice $\left(300 \mathrm{x} \mathrm{g}, 5 \mathrm{~min}, 5^{\circ} \mathrm{C}\right)$. At the end of the first centrifugation, the supernatant fluid was discarded and the cellular pellet was kept at $-80^{\circ} \mathrm{C}$ until further analysis.

qPCR of Nrf2 targetgenes. RNA was extracted from the cell pellet as mentioned earlier using an RNA isolation kit (PureLink ${ }^{\mathrm{TM}}$ RNA kit; Invitrogen; Thermo Fisher Scientific, Inc., Waltham, MA, USA). RNA was quantified and its purity was confirmed by measuring the $\mathrm{OD}_{260 / 280}$, with a value $>1.8$ indicating lack of protein contamination. The extracted RNA $(\sim 10 \mu \mathrm{g})$ was treated with DNase (RQ1 RNase-Free DNase, $1 \mathrm{U} / \mu \mathrm{l}$; Promega Corporation, Madison, WI, USA). DNA-free RNA was then reverse transcribed to obtain cDNA (Superscript II Reverse Transcriptase) using oligo (dT) 12-18 primers (both from
Invitrogen; Thermo Fisher Scientific, Inc.). Amplification of cDNAs for the Nrf2 target genes (cat, sodl, txn, hmoxl, nrf2, nqo1, gclc, gsr, gpxl and gsta2) and for the gapdh gene was performed in $10 \mu \mathrm{l}$ reactions containing $\mathrm{SYBR}^{\circledR}$ Select Master mix (2X; Applied Biosystems; Thermo Fisher Scientific, Inc.), $0.25 \mu \mathrm{M}$ of each primer, $50 \mathrm{nM}$ ROX Low and $25 \mathrm{ng}$ cDNA for the amplification of all tested genes. The utilised primers were based on the literature (Tables I and II). The thermocycling conditions used for the amplification of the aforementioned genes were: $3 \mathrm{~min}$ at $95^{\circ} \mathrm{C} ; 45$ cycles of $15 \mathrm{sec}$ at $95^{\circ} \mathrm{C}, 30 \mathrm{sec}$ at $55^{\circ} \mathrm{C}$ for all the genes in the myoblasts and the majority of genes in the endothelial cells with the exception of cat, and gsta 2 for which $30 \mathrm{sec}$ at $53^{\circ} \mathrm{C}$ were used, followed by $30 \mathrm{sec}$ at $72^{\circ} \mathrm{C}$. Finally, a melting curve was carried out from 53 to $95^{\circ} \mathrm{C}$ to check the specificity of the products. qPCR was performed on a MX3005P system (Stratagene, UK). Amplification efficiencies were $>87 \%$ with $r^{2}$ values $>0.982$ for the genes.

Statistical analysis. Results were analysed by one-way ANOVA followed by Tukey's test for multiple pair-wise comparisons. All the results were expressed as mean \pm SD. Differences were considered significant at $\mathrm{P}<0.05$. Data were analysed using SPSS, version 20.0 (SPSS, Inc., Chicago, IL, USA).

\section{Results and Discussion}

This is a follow-up study from a previous one where nine coffee extracts were analyzed regarding their composition and effect on cellular redox status (28). According to the results, three mono-caffeoylquinic acid isomers (CQAs), namely 3-, 4- and 5-CQA were identified as the main polyphenolic compounds of the extracts, accounting for up to $30.23 \mathrm{mg} / \mathrm{g}$ of coffee with 3-CQA being the most abundant. Furthermore, upon administration to myoblasts and endothelial cells, differential toxicity was observed since green coffee extracts demonstrated higher toxicity towards the myoblasts, while in the endothelial cell line the opposite was observed. Nevertheless, all the extracts resulted in increased reduced GSH levels, an important endogenous antioxidant tripeptide due to its reactive sulfhydryl group (29). Coffee affected GSH levels differently in the two cell lines as in the myoblasts GSH was increased up to approximately $70 \%$, while in the endothelial cells it was increased up to approximately $30 \%$. An interesting observation was that GSH reached a peak concentration at an intermediate coffee extract concentration, while at higher extract concentration GSH was decreased. This finding could be probably attributed to the fact that polyphenols, depending on their concentration, induce a shift of their antioxidant activity towards prooxidant effects (30). Endogenous ROS levels were not affected by the tested extracts, while lipid and protein oxidation levels were slightly reduced, especially in the myoblasts (26).

In the current study, two extracts were selected for further analysis in order to shed light on coffee's mechanism of action. According to the literature, coffee constituents are able to cause Nrf2 derepression (i.e., translocation to the nucleus following detachment from the cytosol-localized Keap1) and concomitantly antioxidant gene expression (31-33). Therefore, the lightly (i.e., for $4 \mathrm{~min}$ ) roasted $C$. arabica coffee extract was selected since it has previously demonstrated the highest antioxidant potency in various assays (34). In addition, its 
Table I. Primers for nuclear factor erythroid 2-related factor 2 target genes in myoblasts.

\begin{tabular}{|c|c|c|}
\hline Gene & Gene ID & Primer (5'-3') \\
\hline cat & 12359 & $\begin{array}{ll}\text { Forward: } & \text { TGAGAAGCCTAAGAACGCAATTC } \\
\text { Reverse: } & \text { CCCTTCGCAGCCATGTG }\end{array}$ \\
\hline sodl & 20655 & $\begin{array}{l}\text { Forward: GTGATTGGGATTGCGCAGTA } \\
\text { Reverse: }\end{array}$ \\
\hline$t x n$ & 22166 & $\begin{array}{l}\text { Forward: CCGCGGGAGACAAGCTT } \\
\text { Reverse: GGAATGGAAGAAGGGCTTGATC }\end{array}$ \\
\hline hmoxl & 15368 & $\begin{array}{l}\text { Forward: CACGCATATACCCGCTACCT } \\
\text { Reverse: CCAGAGTGTTCATTCGAGCA }\end{array}$ \\
\hline$n r f 2$ & 18024 & $\begin{array}{l}\text { Forward: CGAGATATACGCAGGAGAGGTAAGA } \\
\text { Reverse: } \text { GCTCGACAATGTTCTCCAGCTT }\end{array}$ \\
\hline nqol & 18104 & $\begin{array}{l}\text { Forward: TATCCTTCCGAGTCATCTCTAGCA } \\
\text { Reverse: TCTGCAGCTTCCAGCTTCTTG }\end{array}$ \\
\hline gclc & 14629 & $\begin{array}{l}\text { Forward: } \\
\text { Reverse: }\end{array}$ \\
\hline$g s r$ & 14782 & $\begin{array}{l}\text { Forward: GCTATGCAACATTCGCAGATG } \\
\text { Reverse: }\end{array}$ \\
\hline gpxl & 14775 & $\begin{array}{l}\text { Forward: GAAGAACTTGGGCCATTTGG } \\
\text { Reverse: }\end{array}$ \\
\hline gsta2 & 14858 & $\begin{array}{ll}\text { Forward: } & \text { CGTCCACCTGCTGGAACTTC } \\
\text { Reverse: } & \text { GCCTTCAGCAGAGGGAAAGG }\end{array}$ \\
\hline gapdh & 14433 & $\begin{array}{l}\text { Forward: } \text { AACGACCCCTTCATTGAC } \\
\text { Reverse: } \text { TCCACGACATACTCAGCAC }\end{array}$ \\
\hline
\end{tabular}

Table II. Primers for nuclear factor erythroid 2-related factor 2 target genes in endothelial cells.

\begin{tabular}{|c|c|c|c|}
\hline Gene & Access no. & & Primer $\left(5^{\prime}-3^{\prime}\right)$ \\
\hline \multirow[t]{2}{*}{ cat } & 847 & Forward: & CCAGAAGAAAGCGGTCAAGAA \\
\hline & & Reverse: & TGGATGTGGCTCCCGTAGTC \\
\hline \multirow[t]{2}{*}{ sodl } & 6647 & Forward: & AGGGCATCA TCAATTTCGAG \\
\hline & & Reverse: & GGGCCTCAGACTACATCCAA \\
\hline \multirow[t]{2}{*}{$t x n$} & 7295 & Forward: & TTTCCATCGGTCCTTACAGC \\
\hline & & Reverse: & TTGGCTCCAGAAAATTCACC \\
\hline \multirow[t]{2}{*}{ hmoxl } & 3162 & Forward: & GGCCTGGCCTTCTTCACCTT \\
\hline & & Reverse: & GAGGGGCTCTGGTCCTTGGT \\
\hline \multirow[t]{2}{*}{$n r f 2$} & 4780 & Forward: & ATTGCCTGTAAGTCCTGGTCA \\
\hline & & Reverse: & ACTGCTCTTTGGACATCATTTCG \\
\hline \multirow[t]{2}{*}{ nqol } & 1728 & Forward: & GGGCAAGTCCATCCCAACTG \\
\hline & & Reverse: & GCAAGTCAGGGAAGCCTGGA \\
\hline \multirow[t]{2}{*}{ gclc } & 2729 & Forward: & GAAGAAGATATTTTTCCTGTCATTGAT \\
\hline & & Reverse: & CCATTCATGTATTGAAGAGTGAATTT \\
\hline \multirow{2}{*}{ gsr } & 2936 & Forward: & CCAGCTTAGGAATAACCAGCGATGG \\
\hline & & Reverse: & GTCTTTTTAACCTCCTTGACCTGGGAGAAC \\
\hline \multirow[t]{2}{*}{ gpxl } & 2876 & Forward: & CGCTTCCAGACCATTGACATC \\
\hline & & Reverse: & CGAGGTGGTATTTTCTGTAAGATCA \\
\hline \multirow[t]{2}{*}{ gapdh } & 2597 & Forward: & TGCACCACCAACTGCTTAG \\
\hline & & Reverse: & GATGCAGGGATGATGTTC \\
\hline
\end{tabular}

corresponding green extract was also examined due to its peculiar toxicity pattern (i.e., 320-fold more toxic in the myoblasts compared with the roasted one).
Effect of coffee on Nrf2-target gene expression. To test the hypothesis whether Nrf2 derepression is a potential molecular mechanism of extract action, the green and roasted extracts were 

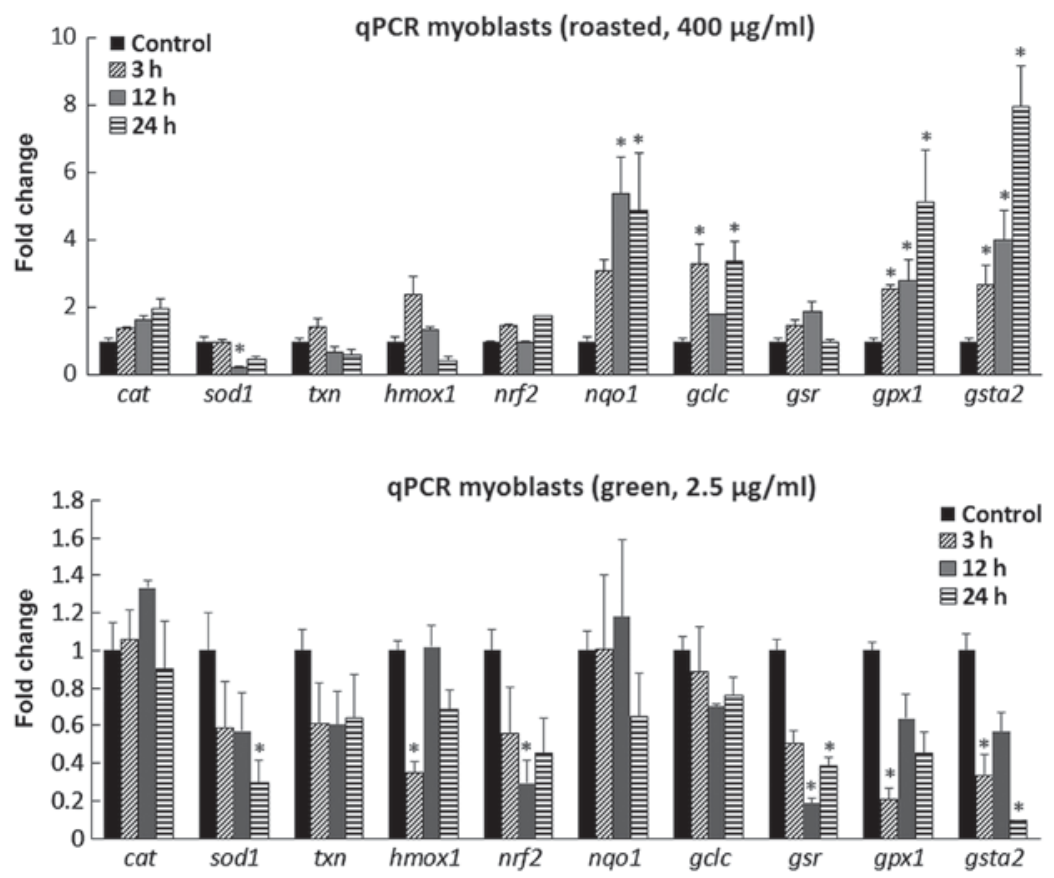

Figure 1. Effect of the tested coffee extracts on Nrf2 target-gene expression in $\mathrm{C} 2 \mathrm{C} 12$ cells. qPCR results are depicted, following administration of coffee extracts on myoblasts for 3,12 or $24 \mathrm{~h}$. Gene expression has been normalised using gapdh expression and the fold-change in gene expression in comparison to the control cells (black bars) is displayed. The results are expressed as mean \pm SD and the asterisk (") symbolises statistical significance at the P<0.05 level. Nrf2, nuclear factor erythroid 2-related factor 2.

administered in the two cell lines at concentrations that caused the maximum increase in GSH levels and sequentially were assessed for their effect on gene expression levels of Nrf2 target genes by qPCR. These genes encode for catalase, superoxide dismutase 1 , thioredoxin, heme oxygenase $1, \mathrm{Nrf} 2, \mathrm{NAD}(\mathrm{P}) \mathrm{H}$ quinone dehydrogenase $1, \gamma$-glutamyl cysteine ligase catalytic subunit, glutathione reductase, glutathione peroxidase 1 and glutathione $\mathrm{S}$-transferase $\alpha 2$. The expression of all these genes is driven by an antioxidant response element (ARE) in their promoter region, recognized by the nuclear localised Nrf2. These proteins are a part of the complex antioxidant system that protects cells from oxidative damage by neutralising free radicals and oxidising agents, therefore extracts or compounds that upregulate their expression may be used as potential antioxidant supplements. In a previous study, the roasted extract was administered in myoblasts and a microarray analysis was conducted, indicating that coffee constituents may act through the Nrf2 pathway (35). As for the used extract concentrations, the roasted extract was administered at $400 \mu \mathrm{g} / \mathrm{ml}$ and the green at $2.5 \mu \mathrm{g} / \mathrm{ml}$ in the myoblasts, while both extracts were administered at $100 \mu \mathrm{g} / \mathrm{ml}$ in the endothelial cells.

According to the qPCR results, in the two cell lines the roasted extract had a more profound effect on gene expression, upregulating most genes compared to the green extract. Specifically, in the myoblasts the roasted extract caused the upregulation of nqol 3.1-, 5.4- and 4.9-fold at 3, 12 and $24 \mathrm{~h}$, respectively (Fig. 1), gclc expression was increased 3.3- and 3.4-fold at 3 and $24 \mathrm{~h}$, respectively, gpxl was upregulated 2.5-, 2.8- and 5.1-fold at 3, 12 and $24 \mathrm{~h}$, respectively, while gsta 2 increased mRNA levels by 2.7-, 3.0- and 8.0-fold at 3, 12 and $24 \mathrm{~h}$, respectively. On the other hand, sodl levels were decreased by $78 \%$. No significant differences were observed for cat, txn, hmoxl, nrf2 and gsr.
The $C$. arabica green extract caused the downregulation of six genes at various time points without upregulating any of the genes (Fig. 1). More specifically, sodl was downregulated by $71 \%$ at $24 \mathrm{~h}, \mathrm{hmox} 1$ was less abundant by $65 \%$ at $3 \mathrm{~h}, n r f 2$ mRNA was $71 \%$ less compared to the control at $12 \mathrm{~h}, g s r$ by 82 and $62 \%$ at 12 and $24 \mathrm{~h}$, respectively, gpxl by $80 \%$ at $3 \mathrm{~h}$ and gsta 2 by 67 and $91 \%$ at 3 and 24 h, respectively. No statistically significant changes were observed for cat, txn, nqol and gclc.

In the flow cytometric analysis of the previous study, both the roasted and the green coffee extracts caused a similar increase in GSH levels (i.e., 70 and 66\%, respectively) at the concentrations used in the qPCR. However, the latter analysis showed that only the roasted extract upregulated the expression of Nrf2 target genes and especially those that partake in GSH metabolism (i.e., gclc, gpxl and gsta2). The increased abundance of these mRNAs, if translated into increased protein levels, may justify the increased GSH levels. In addition, the upregulation of nqol, which encodes for an important antioxidant enzyme that is involved in quinone detoxification, has been displayed in previous studies with coffee (32). Therefore, it can be hypothesised that the roasted extract causes the derepression of Nrf2. This can be attributed to coffee polyphenols such as the 5-caffeoylquinic acid that has been shown to stimulate $N r f 2$ gene expression previously, through oxidation of KEAP1 cysteine residues (e.g., Cys151) that result in the release of $\mathrm{Nrf} 2$, which subsequently enters the nucleus and induces gene expression (36). These results are in agreement with those of another study in which the same extract was administered in the same myoblast cell line at an equal concentration and was subjected to microarray analysis to examine alterations in gene expression levels (35).

By contrast, the green coffee extract resulted in reduced gene expression for some antioxidant enzyme-coding genes. This 

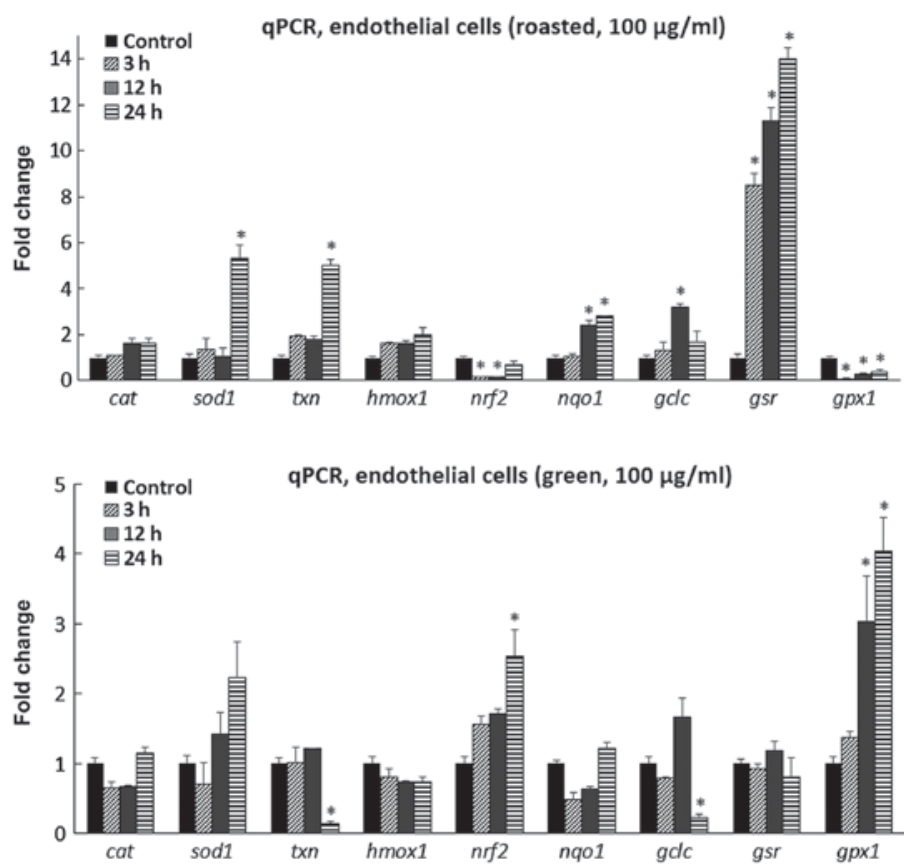

Figure 2. Effect of the tested coffee extracts on $\mathrm{Nrf2}$ target-gene expression in EA.hy926 cells. qPCR results are depicted, following administration of coffee extracts on endothelial cells for 3,12 or $24 \mathrm{~h}$. Gene expression has been normalised using gapdh expression and the fold-change in gene expression in comparison to the control cells (black bars) is displayed. The results are expressed as mean \pm SD and the asterisk $\left(^{*}\right)$ symbolises statistical significance at the $\mathrm{P}<0.05$ level. Nrf2, nuclear factor erythroid 2-related factor 2 .

finding, to the best of our knowledge, has not been previously reported in the literature. Despite the fact that the green extract at this concentration (i.e., $2.5 \mu \mathrm{g} / \mathrm{ml}$ ) resulted in increased GSH levels, this finding cannot be attributed to increased mRNA abundance of GSH metabolism-related genes. However, it is known that polyphenols exert antioxidant activity through a direct free radical scavenging capacity (37). Therefore, it is possible that this scavenging activity of the green coffee extract polyphenols, 'spares' endogenous GSH levels leading to the observed increase. These results, in combination with the high cytotoxicity of the green extract towards myoblasts (at just $20 \mu \mathrm{g} / \mathrm{ml}$ ) indicate that the commercial green coffee extracts should be revisited for potential controversial effects.

In the endothelial cells, the roasted extract caused the increased abundance of sodl mRNA 5.3-fold at $24 \mathrm{~h}$ (Fig. 2). In addition, $t x n$ was also upregulated 5.0-fold at $24 \mathrm{~h}$, while nqol mRNA levels were increased by 2.4 - and 2.82 -fold at 12 and $24 \mathrm{~h}$, respectively. The expression of the gclc gene was increased by 3.2 -fold at $12 \mathrm{~h}$, while $g s r$ abundance was increased by 8.5-, 11.3- and 14.0-fold at 3, 12 and $24 \mathrm{~h}$, respectively. On the other hand, $n r f 2$ mRNA levels were decreased by $84 \%$ at $12 \mathrm{~h}$ and $85 \%$ at $24 \mathrm{~h}$ compared with the control, while gpxl was downregulated by $92 \%$ at $3 \mathrm{~h}, 75 \%$ at $12 \mathrm{~h}$ and $64 \%$ at $24 \mathrm{~h}$. No significant alterations were observed for cat and hmoxl, although a rising trend was evident, particularly, at $24 \mathrm{~h}$. The roasted extract exhibited a distinct profile of affecting the tested genes in the myoblasts versus the endothelial cells. As for the green extract, it caused a 2.5-fold increase in $n r f 2$ mRNA levels at $24 \mathrm{~h}$ and a 3.0- and 4.0-fold increase for gpxl at 12 and $24 \mathrm{~h}$, respectively (Fig. 2). By contrast, lower mRNA levels were observed for $t x n$ by $86 \%$ at $24 \mathrm{~h}$ and $g c l c$ by $77 \%$ at $24 \mathrm{~h}$. No significant changes were evident for the other examined genes.

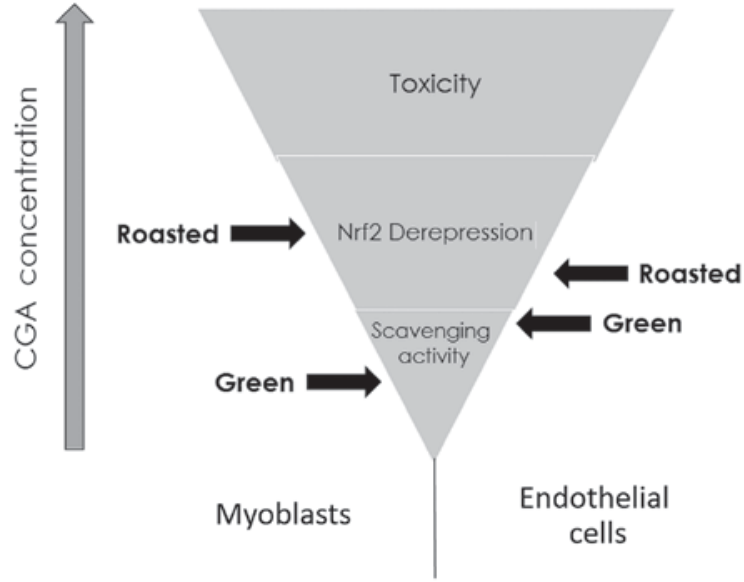

Figure 3. Suggested dose-dependent mechanism of action for the CGAs present in coffee. The potential mechanism of action of the tested coffee extracts is displayed. Their effect on the myoblasts and endothelial cells is dependent on CGA concentration. Low doses (as is the case for the green extract) exert a direct free radical scavenging activity sparing endogenous GSH levels, while at higher doses (as is the case for the roasted extract) Nrf2 derepression occurs, leading to the expression of its target genes. At higher doses, toxicity ensues, possibly due to the pro-oxidant effect of polyphenols. CGA, chlorogenic acids; GSH, glutathione; Nrf2, nuclear factor erythroid 2-related factor 2 .

Taking into consideration the qPCR data along with the dose-dependent, hormetic effect of polyphenols (i.e., direct scavenging/antioxidant at low concentrations - pro-oxidant activity at higher doses, potentially leading to Nrf2 derepression - and toxic past a concentration threshold) (38), a potential mechanism of action for the aforementioned green and roasted extracts can be deduced for both cell lines (Fig. 3). According to the data obtained from the current and 
previous studies, it can be assumed that moderate consumption (e.g., 2-4 cups per day) of lightly roasted coffee (as higher amounts may exhibit tissue-specific cytotoxicity) could elicit potentially beneficial effects through the expression of $\mathrm{Nrf} 2$ target genes. In order to validate these in vitro results, an in vivo study is required so that the effects of bioavailability and metabolism on the potential bioactive compounds will also be taken into consideration.

To conclude, the two coffee extracts differentially affected gene expression in the two tested cell lines. On the one hand, the roasted extract (at $400 \mu \mathrm{g} / \mathrm{ml}$ ) caused the upregulation of four genes (and especially those involved in GSH metabolism) and downregulation in one, while the green extract (at $2.5 \mu \mathrm{g} / \mathrm{ml}$ ) resulted in the downregulation of six genes in the myoblasts. On the other hand, with respect to the endothelial cells, both extracts were administered at the same concentration (i.e, $100 \mu \mathrm{g} / \mathrm{ml}$ ) as in that particular concentration maximum GSH levels were exhibited by flow cytometry. Again, the roasted extract had a more profound effect, as five genes were upregulated, including $g c l c$ and gsr that may explain the increased GSH levels and two were downregulated, including gpxl that could potentially lead to reduced GSH depletion as it utilises this tripeptide as a substrate. The green coffee extract caused an upregulation of only two genes whereas, it downregulated another two. These results highlight the complexity of coffee's molecular mechanism of action, which could partly be explained by the intricate regulation of the antioxidant mechanisms and the interplay between them. Specifically, when some antioxidant mechanisms are activated, some others remain inactive as a compensation adaptive cell response (39).

\section{Acknowledgements}

Not applicable.

\section{Funding}

AP received funding by the Hellenic General Secretariat for Research and Technology (GSRT) and the Hellenic Foundation for Research and Innovation (HFRI). This study was funded by a grant (no. 5042; 'Assessment of antioxidant and anticarcinogenic activity of green and roasted coffee varieties') from Coffee Island SA to DK.

\section{Availability of data and materials}

The datasets used and/or analyzed during the current study are available from the corresponding author on reasonable request.

\section{Authors' contributions}

AP and ASV wrote the manuscript, AP and AEAT conducted the assays. DS collaborated with DK in reviewing the experimental design and the discussion. DK supervised the study while all authors reviewed the manuscript.

\section{Ethics approval and consent to participate}

Not applicable.

\section{Consent for publication}

Not applicable.

\section{Competing interests}

D.A. Spandidos is the Editor-in-Chief for the journal, but had no personal involvement in the reviewing process, or any influence in terms of adjudicating on the final decision, for this article.

\section{References}

1. Ray PD, Huang BW and Tsuji Y: Reactive oxygen species (ROS) homeostasis and redox regulation in cellular signaling. Cell Signal 24: 981-990, 2012.

2. Halliwell B: Free radicals and other reactive species in disease. In: eLS. John Wiley \& Sons, Ltd., Hoboken, NJ, 2001.

3. Sosa V, Moliné T, Somoza R, Paciucci R, Kondoh H and LLeonart ME: Oxidative stress and cancer: An overview. Ageing Res Rev 12: 376-390, 2013.

4. Rochette L,Zeller M, Cottin Y and Vergely C: Diabetes, oxidative stress and therapeutic strategies. Biochim Biophys Acta 1840: 2709-2729, 2014.

5. Veskoukis AS, Goutianos G, Paschalis V, Margaritelis NV, Tzioura A, Dipla K, Zafeiridis A, Vrabas IS, Kyparos A and Nikolaidis MG: The rat closely mimics oxidative stress and inflammation in humans after exercise but not after exercise combined with vitamin C administration. Eur J Appl Physiol 116: 791-804, 2016.

6. Spanidis Y, Goutzourelas N, Stagos D, Mpesios A, Priftis A, Bar-Or D, Spandidos DA, Tsatsakis AM, Leon G and Kouretas D: Variations in oxidative stress markers in elite basketball players at the beginning and end of a season. Exp Ther Med 11: 147-153, 2016.

7. Deanfield JE, Halcox JP and Rabelink TJ: Endothelial function and dysfunction: Testing and clinical relevance. Circulation 115: 1285-1295, 2007.

8. Victor VM, Rocha M, Solá E, Bañuls C, Garcia-Malpartida $\mathrm{K}$ and Hernández-Mijares A: Oxidative stress, endothelial dysfunction and atherosclerosis. Curr Pharm Des 15: 2988-3002, 2009.

9. Kokura S, Wolf RE, Yoshikawa T, Granger DN and Aw TY: Molecular mechanisms of neutrophil-endothelial cell adhesion induced by redox imbalance. Circ Res 84: 516-524, 1999.

10. Rhee SG: Cell signaling. H2O2, a necessary evil for cell signaling. Science 312: 1882-1883, 2006.

11. Woywodt A, Bahlmann FH, De Groot K, Haller H and Haubitz M: Circulating endothelial cells: Life, death, detachment and repair of the endothelial cell layer. Nephrol Dial Transplant 17: 1728-1730, 2002

12. Birben E, Sahiner UM, Sackesen C, Erzurum S and Kalayci O: Oxidative stress and antioxidant defense. World Allergy Organ J 5: 9-19, 2012.

13. Pastore A, Federici G, Bertini E and Piemonte F: Analysis of glutathione: Implication in redox and detoxification. Clin Chim Acta 333: 19-39, 2003.

14. Landete JM: Dietary intake of natural antioxidants: Vitamins and polyphenols. Crit Rev Food Sci Nutr 53: 706-721, 2013.

15. Pandey KB and Rizvi SI: Plant polyphenols as dietary antioxidants in human health and disease. Oxid Med Cell Longev 2: 270-278, 2009.

16. Goutzourelas N, Stagos D, Spanidis Y, Liosi M, Apostolou A, Priftis A, Haroutounian S, Spandidos DA, Tsatsakis AM and Kouretas D: Polyphenolic composition of grape stem extracts affects antioxidant activity in endothelial and muscle cells. Mol Med Rep 12: 5846-5856, 2015.

17. Heckman MA, Weil J and Gonzalez de Mejia E: Caffeine (1, 3, 7-trimethylxanthine) in foods: A comprehensive review on consumption, functionality, safety, and regulatory matters. J Food Sci 75: R77-R87, 2010.

18. Higdon JV and Frei B: Coffee and health: A review of recent human research. Crit Rev Food Sci Nutr 46: 101-123, 2006.

19. Murthy PS and Naidu MM: Recovery of phenolic antioxidants and functional compounds from coffee industry by-products. In: Food and Bioprocess Technology. Vol 5. Springer, Berlin, pp897-903, 2010 
20. Henry-Vitrac C, Ibarra A, Roller M, Mérillon JM and Vitrac X Contribution of chlorogenic acids to the inhibition of human hepatic glucose-6-phosphatase activity in vitro by Svetol, a standardized decaffeinated green coffee extract. J Agric Food Chem 58: 4141-4144, 2010.

21. Park JB: Isolation and quantification of major chlorogenic acids in three major instant coffee brands and their potential effects on $\mathrm{H}_{2} \mathrm{O}_{2}$-induced mitochondrial membrane depolarization and apoptosis in PC-12 cells. Food Funct 4: 1632-1638, 2013.

22. Xu J-G, Hu Q-P and Liu Y: Antioxidant and DNA-protective activities of chlorogenic acid isomers. J Agric Food Chem 60: 11625-11630, 2012.

23. Jaiswal R, Matei MF, Golon A, Witt M and Kuhnert N: Understanding the fate of chlorogenic acids in coffee roasting using mass spectrometry based targeted and non-targeted analytical strategies. Food Funct 3: 976-984, 2012.

24. Daglia M, Racchi M, Papetti A, Lanni C, Govoni S and Gazzani G: In vitro and ex vivo antihydroxyl radical activity of green and roasted coffee. J Agric Food Chem 52: 1700-1704, 2004

25. Priftis A, Papikinos K, Koukoulanaki M, Kerasioti E, Stagos D, Konstantinopoulos K, Spandidos DA, Kermenidou M, Karakitsios S, Sarigiannis D, et al: Development of an assay to assess genotoxicity by particulate matter extract. Mol Med Rep 15: 1738-1746, 2017.

26. Kamiyama M, Moon J-K, Jang HW and Shibamoto T: Role of degradation products of chlorogenic acid in the antioxidant activity of roasted coffee. J Agric Food Chem 63: 1996-2005, 2015.

27. Gawlik-Dziki U, Świeca M, Dziki D, Kowalska I, Pecio Ł, Durak A and Seczyk Ł: Lipoxygenase inhibitors and antioxidants from green coffee - Mechanism of action in the light of potential bioaccessibility. Food Res Int 61: 48-55, 2014.

28. Priftis A, Panagiotou EM, Lakis K, Plika C, Halabalaki M, Ntasi G, Veskoukis AS, Stagos D, Skaltsounis LA and Kouretas D: Roasted and green coffee extracts show antioxidant and cytotoxic activity in myoblast and endothelial cell lines in a cell specific manner. Food Chem Toxicol 114: 119-127, 2018.

29. Aquilano K, Baldelli S and Ciriolo MR: Glutathione: New roles in redox signaling for an old antioxidant. Front Pharmacol 5: 196, 2014.

30. Sakihama Y, Cohen MF, Grace SC and Yamasaki H: Plant phenolic antioxidant and prooxidant activities: Phenolics-induced oxidative damage mediated by metals in plants. Toxicology 177 $67-80,2002$
31. Volz N, Boettler U, Winkler S, Teller N, Schwarz C, Bakuradze T, Eisenbrand G, Haupt L, Griffiths LR, Stiebitz H, et al: Effect of coffee combining green coffee bean constituents with typical roasting products on the Nrf2/ARE pathway in vitro and in vivo. J Agric Food Chem 60: 9631-9641, 2012.

32. Higgins LG, Cavin C, Itoh K, Yamamoto Mand Hayes JD: Induction of cancer chemopreventive enzymes by coffee is mediated by transcription factor Nrf2. Evidence that the coffee-specific diterpenes cafestol and kahweol confer protection against acrolein. Toxicol Appl Pharmacol 226: 328-337, 2008.

33. Boettler U, Sommerfeld K, Volz N, Pahlke G, Teller N, Somoza V, Lang R, Hofmann T and Marko D: Coffee constituents as modulators of Nrf2 nuclear translocation and ARE (EpRE)-dependent gene expression. J Nutr Biochem 22: 426-440, 2011.

34. Priftis A, Stagos D, Konstantinopoulos K, Tsitsimpikou C, Spandidos DA, Tsatsakis AM, Tzatzarakis MN and Kouretas D: Comparison of antioxidant activity between green and roasted coffee beans using molecular methods. Mol Med Rep 12: 7293-7302, 2015

35. Priftis A, Goutzourelas N, Halabalaki M, Ntasi G, Stagos D, Amoutzias GD, Skaltsounis LA and Kouretas D: Effect of polyphenols from coffee and grape on gene expression in myoblasts. Mech Ageing Dev (In press)

36. Liang $\mathrm{N}$ and Kitts DD: Role of chlorogenic acids in controlling oxidative and inflammatory stress conditions. Nutrients $8: 1-20$, 2015.

37. Sirota R, Gibson D and Kohen R: The role of the catecholic and the electrophilic moieties of caffeic acid in Nrf2/Keap1 pathway activation in ovarian carcinoma cell lines. Redox Biol 4: 48-59, 2015.

38. Houghton CA, Fassett RG and Coombes JS: Sulforaphane and other nutrigenomic Nrf2 activators: Can the clinician's expectation be matched by the reality? Oxid Med Cell Longev 2016: 7857186, 2016

39. Alvarez $\mathrm{S}$ and Boveris A: Antioxidant adaptive response of human mononuclear cells to UV-B: Effect of lipoic acid. J Photochem Photobiol B 55: 113-119, 2000. 